\title{
PERJUMPAAN ETIS DENGAN WAJAH YANG-LAIN: MEMBACA KARYA SASTRA DENGAN “ETIKA” LEVINASIAN
}

\author{
Achmad Fawaid \\ Ilmu Sastra, Fakultas Ilmu Budaya, UGM \\ Email: fawaidachmad@gmail.com
}

\begin{abstract}
Abstrak
Tulisan ini ingin memperkenalkan suatu pendekatan teoretis dalam studi-studi kesastraan yang terkait relasi antara etika dan sastra. Untuk itulah, konsep mengenai perjumpaan etis, yang digagas oleh Emmanuel Levinas, dipilih sebagai upaya untuk menggambarkan relasi tersebut dalam karya-karya Danarto dan Putu Wijaya. Tulisan ini menggunakan riset filosofis sebagai landasan metodologisnya sekaligus untuk mencari kemungkinan digunakannya etika Levinasian sebagai metode analisis karya sastra. Dari pembacaan dan analisis tersebut, ada beberapa temuan =sementara' yang diperoleh: (1) karya Danarto dan Putu Wijaya dapat dikategorikan sebagai karya-karya yang memiliki dimensi etis dan (2) ada beberapa implikasi lanjutan yang muncul setelah diterapkannya analisis awal terhadap hubungan antara etika Levinasian dan karya sastra tersebut.
\end{abstract}

Kata kunci: relasi, etika, sastra, Levinas, Danarto dan Putu Wijaya

\section{Abstract}

This paper aims to introduce a theoretical approach to literary studies regarding with relation between ethics and literature. For this purpose, an ethical encounter, flourished by Emmanuel Levinas, will be highlighted to figure out that relation within Danarto and Putu Wijaya's narratives. The philosophical research is a kind of methodology on which this paper is based in order to search a possible way of adopting Levinasian ethics as method of literary analysis. It has resulted in some initial findings: (1) Danarto and Putu Wijaya's narratives can be regarded as ones conceiving ethical dimension and (2) some implications emerge subsequent to the analysis of relationship between Levinasian ethics and literature.

Keywords: relation, ethics, literature, Levinas, Danarto and Putu Wijaya

\section{Pendahuluan}

Relasi antara sastra dan etika sebenarnya memiliki sejarah panjang yang dapat kita lihat, Teoretis Sastra (Literature's Theoretical Era) pembacaan etis atas karya sastra justru semakin memudar. Pada saat itu, relasi antara sastra dan etika yang menjadi warisan pemikiran Barat pasca-Pencerahan kurang dihiraukan keberadaannya. Studi-studi yang fokus pada sastra-etika tidak hanya dianggap sebagai sesuatu yang out of date, melainkan juga, dan yang lebih penting, sebagai kerja intelektual yang telah dinodai oleh peristiwa-peristiwa historis yang terjadi sepanjang satu abad terakhir. Salah satu yang mungkin paling diingat banyak orang adalah ketika Martin Heidegger, filsuf Jerman tersohor yang dijuluki "bermata elang" itu belakangan juga diikuti oleh filsuf dekonstruktif Prancis, Paul de Man, justru mengungkapkan simpati fasisnya terhadap Nazi.

Pengenalan kembali etika sebagai perangkat penting dalam teori kesusastraan hanya muncul dalam tahun-tahun terakhir ini, atau jika kita meyakini akurasi Geoffrey Harpham (1995: 389), kita dapat menyatakan bahwa "pada atau sekitar 1 Desember 1987 (ketika simpati fasis muda de Man tersebar di berbagai media), watak teori kesusastraan di dunia telah mengalami perubahan".Todd Davis dan Kenneth Womack (2001; x) juga menyatakan bahwa "salah satu yang menandai perkembangan studi-studi kesusastraan kontemporer adalah kembalinya subjek pada ranah etis"(subject to the ethical turn that marks contemporary literary studies). Akhir-akhir ini, hampir semua pemikir posmodern percaya bahwa peran etika sastra lebih dari sekadar 
"melatih sensibilitas etis" (train[ing] ethical sensibility) (Newton, 1995: 9) atau menyajikan "praktik-praktik pedagogis dan edukatif" (pedagogical and educational practices) (Eskin, 2004: 576) sebagaimana yang dibayangkan oleh para humanis klasik. Robert Eaglestone (1997: 175), misalnya, percaya bahwa ketika pembaca "dibuat tidak betah dengan teks" (made to feel not at home with the text), berarti sastra tersebut telah membangun sikap etis.

Argumentasi yang ingin dihadirkan di sini adalah bahwa sastra-sastra posmodern dapat merepresentasikan perjumpaan etis yang sulit atau bahkan tidak mungkin diidentifikasi dan dikategorisasi dalam momen kekinian absolut dengan dua cara penting. Pertama, teknik-teknik stilistik sastra yang cenderung 'disruptif' dapat menfasilitasi kesadaran etis pembaca dan, kedua, bahwa representasi sastra atas modelmodel intersubjektivitas yang 'disruptif' ini merupakan strategi tematik yang dengannya teks sastra merepresentasikan kesadaran etis tokoh-tokoh di dalamnya.

Terkait dengan penelitian ini, beberapa pemikir posmodern yang berusaha meruntuhkan kedaulatan teks, dan dengan demikian sentralitas pembaca, antara lain adalah Jacques Derrida dan tentu saja Emmanuel Levinas. Dua filsuf Prancis ini adalah kawan dekat, yang pemikirannya sama-sama radikal. Jika Derrida menawarkan strategi pembacaan dekonstruksi untuk menghancurkan tradisi logosentris yang selama ini mengakar dalam ontologi filsafat Barat, Levinas menawarkan etika untuk membalikkan tradisi filsafat yang sangat egologis menuju filsafat yang memperhatikan Yang-Lain, the Other, liyan: etika sebagai filsafat pertama (ethics as fist philosophy) (Levinas, 1989: 84).

Dengan etikanya, Levinas mau membuka kembali ruang "kesadaran moral" filsafat. Orisinalitas kajian Levinas, menurut Peperzak (1997: 12), terletak pada pertimbangannya atas heterogenitas pengalaman dan keunikan dari manusia sebagai subjek etis. Levinas bisa dikatakan telah melampaui apa yang diusahakan Immanuel Kant dalam etikanya. Sejak Kant, etika mendapat perhatian tersendiri dan bahkan masuk dalam satu disiplin khusus yang disebut "akal praktis". Kant berasumsi bahwa manusia adalah tujuan dari seluruh tindakan moral. Dengan memperlakukan manusia demikian, kita akan terhindar dari tindakan tak bermoral dan mencapai kebaikan. Berbeda dengan Kant, Levinas menganggap bahwa sumber dari moralitas dan tindakan etis bukanlah apa yang disebut Kant sebagai "esensi manusia" (die Menschheit). Tindakan etis hanya muncul tatkala manusia justru hadir dan tampak kepada kita dalam wujud Yang-Lain.

Berbeda dengan Derrida yang sejak dulu dikenal sebagai filsuf yang berfilsafat dengan teks, pemikiran Levinas dalam kritik kesusastraan kontemporer-untuk tidak mengatakan tidak ada - masih jarang didengar (baca misalnya Robbins, 1999; Davis, 2009). Mungkin karena Levinas cenderung bergerak dalam wilayah etika- fenomenologi, pemikiran-pemikirannya lebih didedikasikan untuk menunjukkan relasi etis antara Aku dan Yang-Lain; antara ego dan the Other. Akan tetapi, bukan berarti Levinas sama sekali an sich terhadap sastra. Beberapa tulisannya, seperti "God and Philosophy" (1989: 166-189) dan "The Other in Proust" (1989: 160165), dikarang salah satunya untuk mencermati teks-teks sastra, semisal novel the Brothers Karamazov-nya Dostoevsky dan serial In Search of Lost Time-nya Marcel Proust.

\section{Levinas dan Wajah Yang-Lain}

Emmanuel Levinas, filsuf Yahudi asal Prancis, adalahorang pertamayang pemikirannya menandai pergeseran penting dari ontologi ke etika, dari metafisika yang memprioritaskan logos ke metafisika yang mengedepankan loxos, dari sejarah yang terpusat pada ego ke sejarah yang mengawali lahirnya the other atau "yang lain". Levinas muncul ketika filsafat tengah didera krisis epistemologis yang akut. Heidegger yang memulai filsafatnya dengan mempertanyakan Ada (Being) telah mencetuskan krisis yang sama pada ranah ontologi. Perbedaannya, jika Heidegger berusaha memulihkan krisis itu dengan kembali kepada Ada dan kemewaktuan 
yang terstruktur melalui Ada, maka Levinas justru menggeser orientasi ontologi Heidegger ke wilayah etika. Dengan memasuki etika, dan menegaskan pentingnya etika di atas metafisika dan ontologi, Levinas mengafirmasi sekali lagi "berakhirnya" filsafat sebagai epistemologi atau ontologi.

Meskipun begitu luas dan kompleks, setidak-tidaknya ada lima hal yang dapat dirumuskan dari gagasan etika Levinasian, yakni Yang-Lain (AutruilAutre), Wajah (le Visage), Yang-Tak-Terbatas (Infinity), Proksimitas (Proximity), dan Eksterioritas (Exteriority). Lima gagasan inilah yang nantinya menjadi konsep- konsep paling menentukan sepanjang menganalisis karya-karya Danarto dan Putu Wijaya.

\section{Yang-Lain (Autrui/Autre)}

Bagi Levinas, Yang-Lain adalah pembuka horizon keberadaan kita, bahkan pendobrak menuju transendentalitas kita. Manusia pada hakikatnya terasing atau alien satu sama lain. Untuk menjembatani itu, Levinas menawarkan apa yang disebutnya sebagai perjumpaan etis. Perjumpaan yang dimaksud adalah perjumpaan dengan Yang- Lain. Yang-Lain adalah orang lain, sesama manusia, pribadi yang lain sebagai person dalam keluhuran martabatnya. YangLain juga bisa berarti mereka yang hendak kita rengkuh seutuhnya, mereka yang kita bayangkan sebagai objek yang dapat kita pahami alteritasnya. Bahkan, Levinas membawa konsep Yang-Lain ini dalam tataran "religious". Baginya, Yang-Lain bisa berupa Yang Sama Sekali Lain (the wholly other): Allah. Dialah Yang-Lain, yang tidak dapat dipikirkan dalam kerangka ontologi dan metafisika.

Keberadaan Yang-Lain inilah yang menjadi titik sentral Levinas untuk menggugat tradisi filsafat yang sepanjang sejarahnya cenderung mengabsolutkan ego. Sejak Plato hingga Heidegger, filsafat tak ubahanya sebuah proyek totalisasi: merengkuh Yang- Lain dalam kelainannya dan Yang-Beda dalam perbedaannya. Yang-Lain selalu ingin dipahami dalam metafisika kehadiran (metaphysics of presence). Padahal, bagi Levinas, Yang-Lain selalu ada di luar inteligibelitas ego. Yang-Lain adalah sesuatu yang eksterior, transenden, Yang-TakTerbatas, yang melampaui kesadaran dan dunia ego.

Akan tetapi, Yang-Lain bukanlah alterego, bagiku ia bukan "aku yang lain”, ego yang memelarkan diri dalam bentuk yang lain. "YangLain, sebagai yang lain", tulis Levinas, "bukan hanya sebuah alter-ego. Ia adalah sesuatu yang bukan diriku" (Levinas, 1969: 190; Derrida, 1978: 125). Aku tidak dapat menghampiri Yang-Lain dengan bertolak dari "aku". Dia sama sekali lain. Yang-Lain adalah Pendatang, Orang Asing (L'Etranger).

\section{Wajah (le Visage)}

Yang-Lain pertama-tama tampak padaku melalui Wajahnya (Visage). Bagi Levinas, Wajah bukanlah bentuk fisik sehari-hari. Ia melampaui segala kategori ontologis. Wajah, menurut Levinas, "hadir dalam penolakannya untuk direngkuh" (Levinas, 1969: 194). Wajah inilah yang menjadi penanda Yang-Lain, yang menggugatku, untuk keluar dari subjektivitasku, untuk menyapanya, dan berjumpa dengannya secara etis. Bagi Levinas, Wajah merupakan "cara di mana Yang-Lain (l'Autre) memperlihatkan dirinya, melampaui gagasan mengenai yang lain dalam diriku" (Levinas: 1969: 50). Wajah merupakan "signifikasi tanpa konteks" (Levinas, 1982:86). Dengan kata lain, Wajah merupakan cara di mana YangLain menampakkan dirinya di hadapanku yang melampaui kemampuanku untuk menilai, memahami, dan mentematisasikannya.

Dalam salah satu wawancaranya, Levinas pernah berbicara tentang tiga momen etis epifani Wajah (Levinas, 2001: 127). Momen pertama terdapat dalam sifat tegak- lurus Wajah yang memperlihatkan ketelanjangan dan ketakberdayaan. Momen kedua epifani Wajah terdapat dalam relasinya dengan Yang-Lain yang mengundang penyapaan (interpelasi), sejenis relasi etis yang tidak bisa dihindarkan oleh ego saat bertatapan dengan Wajah Yang-Lain. Momen ketiga epifani Wajah adalah bahwa Wajah 
melakukan tuntutan atas diriku. Ia berbicara dalam kepasifan dan kediamannya, dan ketika ia berbicara, keberadaanku diinterupsi olehnya. "Wajah menatapku dan memanggilku. Ia menuntut padaku. Apa yang ia minta? Jangan tinggalkan ia sendirian” (Levinas, 1998: 55).

\section{Yang-Tak-Terbatas (Infinity)}

Totality and Infinity: An Essay on Exteriority, yang terbit pada tahun 1961 (1969 dalam versi bahasa Inggris), boleh dikatakan merupakan upaya Levinas untuk melampaui fenomenologi dan bahkan seluruh tradisi filsafat. Ada tiga hal yang ia bedakan dalam buku itu, yaitu Totalitas, Yang-Tak-Terbatas, dan Eksterioritas. Ketiganya merupakan kunci bagi Levinas untuk membuka ranah baru etika yang disebutkan di atas.

"Totalitas" adalah istilah Levinas untuk menunjuk pola berpikir dan sistem filosofis yang bertolak dari ego, kesadaran, atau "aku" (the T). Filsafat adalah suatu cara berpikir yang ingin mengintegrasikan segala hal yang tak dipahami agar menjadi dipahami oleh kesadaran. Karena itu filsafat selalu bertolak dari keinginan ego untuk memahami Yang- Lain, yang ada di luar dirinya. Satu keinginan terpendam yang terusmenerus menggairahkan filsafat dalam usaha kerasnya adalah kehendak untuk mengejar totalitas, yakni mengejar pemahaman yang utuh dan final tentang sesuatu. Kehendak ini bukannya tak netral dari kekerasan. Menurut Levinas (1969: 32), dengan mengejar totalitas untuk sepenuhnya dimasukkan dan "dikurung"dalam kungkungan ego, filsafat diam-diam telah melakukan kekerasan.

Totalitas, seperti sepotong es beku, didobrak oleh Yang-Tak-Terbatas (the Infinite). Yang-Tak-Terbatas adalah sesuatu yang tak mampu untuk sepenuhnya dipahami, yakni Yang-Lain, yang berbeda dari "aku”, ego, atau kesadaran. Yang-Tak-Terbatas muncul dan meretakkan keutuhan ego. Kemunculannya, menurut Levinas, mengetuk ego untuk keluar dari diri dan kesadarannya.

Ketika berbicara tentang Yang-TakTerbatas, nada Levinas terkesan semakin muram. Tampaknya Levinas benar-benar gigih memperlihatkan upayanya membalik orientasi filsafat yang terlalu bersibuk dengan "ego" untuk semakin berpaling kepada Yang-Lain. Di sini Levinas memberi bobot penting pada konsep Yang-Tak-Terbatas yang diperkenalkannya, dengan menekankan bahwa Yang-Tak-Terbatas hampir selalu berarti YangLain (Autrui, l'Autre). Dengan demikian, YangTak-Terbatas selalu berwujud dalam diri YangLain dan pengalaman bertemu dengannya.

\section{Proksimitas (Proximity)}

Momen etis penampakan Wajah YangLain memberikan implikasi metafisis yang lebih dari sekadar menyapa (interpelasi), tetapi juga bertanggung jawab atasnya. Di hadapan sorot tajam tatapan Wajah, aku menjadi "sandera" (hostage) bagi Yang-Lain (Levinas,1989: 84). Ketersanderaan inilah yang memutus lingkaran setan egoisme yang selalu menubuh dalam diri manusia, terutama dalam tradisi filsafat selama ini.

Akan tetapi, tanggung jawabku pada Yang-Lain bukanlah sebuah relasi yang lahir dari alienasi dan perasaan bersalah. Istilahistilah ontologis ini hanya mereduksi YangLain seolah-olah sebagai pengalaman individual semata. Aku tidak merasa bersalah sehingga aku bertindak. Aku merespons bukan karena aku merasa terasing. Ini bukanlah perasaan atau tindakan yang sepenuhnya etis dalam pengertian Levinasian. Proksimitas Yang-Lain, kedekatanku dengan-mu, mendahului segala perasaan atau pengalaman yang berasal dari dan kembali pada ego.

Proksimitas antara diri dan Yang-Lain secara langsung menandai tuntutan etis untuk tunduk di hadapan Yang-Lain, Yang-TakTerbatas, dalam kelainannya yang tidak bisa direngkuh seutuhnya. Proksimitas ini persisnya merupakan sebuah tuntutan karena sifatnya yang non-relasi, pasif, langsung (immediate), dan tanpa-mediasi (non-mediate). Tidak ada totalitas utuh antara aku dan kamu; aku dan Yang-TakTerbatas. 


\section{Eksterioritas (Exteriority)}

Levinas lebih jauh mengaitkan YangTak-Terbatas dan Wajah dengan konsepnya tentang "eksterioritas". Eksterioritas adalah kondisi ketika kemunculan Yang-Lain tidak dapat sepenuhnya aku kuasai dalam kedirianku. Eksterioritas berarti suatu keadaan di mana Yang-Lain "ada di luar" diriku, dan membuatku mengerti akan keterbatasanku dan kehadirannya sebagai Yang-Tak-Terbatas. Ia ada di luar sana, telanjang, menggigil, dan memanggil-manggil kesadaranku untuk menemui dan bertatap muka dengannya (Levinas, 1969: 45; bdk. Bachelard, 1964: 32).

Yang-Eskteriorhampirselalumengganggu stabilitas Yang-Interior. Stabilitas itu muncul ketika ego lebih memilih menganggap YangLain sebagaimana (menurut) dirinya sendiri. Yang-Lain haruslah disadari dalam kedirian, dalam diri yang paling dalam, yang interior dalam diriku. Yang-Lain, yang misteris, harus disibak dan ditampakkan ke permukaan. Tidak boleh ada satu pun yang tampak asing, yang tak terjamah oleh ego. Semuanya harus diketahui dan dikenali. Inilah interioritas ego yang paling mendasar.

\section{Levinas dan Sastra}

Meskipun tidak sering bergelut di bidang ini, bukan berarti Levinas menghindari dunia sastra. Jauh sebelum membicarakan Dostoevsky dan Proust, Levinas sebenarnya pernah memiliki relasi dekat —meski tak langsung - dengan beberapa novelis Yahudi yang juga pernah mendekam di kamp-kamp konsentrasi. Dua di antara novelis tersebut adalah Elie Wiesel dan Primo Levi.

Relasi dekat namun tak langsung ini terjadi karena 1) ketiganya merupakan penulis yang sama-sama mendasarkan pemikirannya pada etika, bedanya: jika Levinas lebih fokus pada filsafat, Wiesel dan Levi lebih bergelut di dunia sastra, selain itu 2) baik Levinas maupun Elie Wiesel sebenarnya pernah menjadi sahabat satu kelas yang belajar pada salah seorang guru Talmud bernama Monsieur Chouchani (Jacobwitz, 2011: 1). Sang guru inilah yang turut mempengaruhi pemikiran keduanya tentang pentingnya etika tanggung jawab (ethics of responsibility). Siapakah gerangan sang guru ini?

Chouchani dikenal sebagai orang yang misterius lantaran hingga saat ini tidak ada satupun yang mengetahui siapa nama asli sang guru. Meninggal pada 1968, Chouchani adalah salah seorang guru Yahudi yang mengajar beberapa siswa di Eropa setelah Perang Dunia II. Banyak muridnya yang berhasil menjadi tokoh ternama. Dua di antaranya, tentu saja, adalah Emmanuel Levinas, sang filsuf Prancis yang terkenal dengan gagasan etika-nya, dan Elie Wiesel, novelis Yahudi yang pernah memperoleh Nobel Perdamaian pada tahun 1986.

Selain keduanya adalah murid Chouchani, tidak ada catatan yang secara lengkap mempertemukan Levinas dan Wiesel. Meski demikian, seperti yang telah dijelaskan, kesamaan Levinas dan Wiesel terletak pada bahwa keduanya adalah orang Yahudi, orang yang sama-sama pernah merasakan hidup di kamp-kamp konsentrasi Nazi, yang pernah lama tinggal di Prancis (namun tak satupun yang lahir di sana; Levinas lahir di Lithuania, 1906, sementara Wiesel lahir di Romania, 1928), yang sama-sama mempelajari Talmud (kitab hitam umat Yahudi yang kontroversial itu) meski dengan cara dan latar belakang hidup yang berbeda. Berikut ini akan dijelaskan-dengan sangat ringkas-beberapa titik keberangkatan kemungkinan dijadikannya etika Levinasian sebagai metode analisis sastra.

\section{Sastra "Yang Tak Terbatas"}

Etika Levinasian merupakan kritik terhadap totalitas egologis melalui Yang-Lain, Yang-Tak-Terbatas. Kritik ini ditujukan pada subjek (ego) yang berusaha merengkuh dan memahami secara total fenomena atau objek tertentu, seraya menunjukkan bahwa fenomena/ objek tersebut adalah Yang-Lain bagi mereka, Yang-Tak-Terbatas, dalam alteritasnya yang mustahil untuk dipahami. Dalam konteks karya sastra, totalitas ini bisa muncul dari dua 
hal: 1) kemungkinan pembacaan teks sastra yang berusaha membangun semacam totalitas pemahaman terhadap tokoh-tokoh atau kondisikondisi tertentu di dalamnya namun teks tersebut justru memperlihatkan ambiguitas dan paradoksikalitasnya yang tak mudah dipahami, dan 2) usaha pemahaman tokoh-tokoh terhadap tokoh lain dalam teks tersebut, namunia (tokoh yang-lain ini) menolak untuk dipahami dan diontologisasi oleh mereka, baik karena sikap maupun karena ucapan-ucapannya yang subtil dipahami dalam kerangka kehadiran (presence). Kaitannya dengan riset ini, peneliti berusaha memunculkan kritik itu ke permukaan. Kritik tersebut bisa muncul, tidak hanya dari penelitisebagai-pembaca, tetapi juga dari tokoh-tokoh yang menolak untuk ditematisasi dan dipahami secara ontologis.

\section{Sastra yang "Eksterior"}

Etika Levinasian merupakan penanda ekterioritas radikal bagi Yang-Lain (the Other). Eksterioritas merupakan kondisi ketika kemunculan Yang-Lain tidak dapat sepenuhnya aku kuasai dalam kedirianku. Eksterioritas berarti suatu keadaan di mana Yang-Lain "ada di luar" diriku (eksterior), dan membuatku mengerti akan keterbatasanku dan kehadirannya sebagai Yang-Tak-Terbatas. Dalam membaca karya sastra, eksterioritas ini dapat diterapkan dengan cara menampilkan keunikan-keunikan, kemisteriusan-kemisteriusan, dan keganjilankeganjilan dalam diri Yang-Lain sebagai bentuk eksterioritas/ketakmungkinannya untuk dipahami secara utuh. Jika mengikuti pandangan Gaston Bachelard tentang "puisi ruang" (poetics of space), dapat mengakatan bahwa jika ontologi hendak menonjolkan ruang-dalam (suasana nyaman, keakraban, konvensionalitas, kebahagiaan) dalam karya sastra, maka etika Levinasian justru berusaha menampilkan ruangobjektif (kemisteriusan, keanehan, keganjilan, nilai-nilai puitis dan imajinatif, bahkan-jika mungkin-ketakmungkinan-ketakmungkinan) untuk mengganggu kenyamanan dan stabilitas ruang-dalam (Bachelard, 1964: 32).

\section{Sastra yang "Primodial-Etis"}

Etika Levinasian menuntut tanggung jawab primordial pada Yang-Lain. Menurut Levinas, Yang-Lain menampakkan Wajahnya padaku dengan keadaan polos, telanjang, menggigil, yang terus memanggilku, menuntutku untuk bertanggung jawab padanya, sejenis tanggung jawab primordial yang mendahului segala relasi formal apa pun. Tanggung jawab etis ini merupakan bagian dari momen transendensi, yakni momen keterpecahan diri saat diri merasakan totalitasnya telah retak ketika bertatapan dengan Wajah Yang-Lain. Dalam karya sastra, tanggung jawab primordial ini dapat ditelusuri dari relasi etis antartokoh satu dengan tokoh yang lain. Etika Levinasian tidak hanya berhenti pada penemuan relasi etis ini, tetapi juga pada implikasi lebih lanjut dari relasi tersebut, yakni tanggung jawab etis. Akan tetapi, tanggung jawab ini tidak bisa disamakan begitu saja dengan tindakan tanggung jawab formal pada umumnya, seperti menolong, membantu, dan menghormati orang lain, yang seringkali didasarkan pada perasaan-perasan kognitif seperti rasa bersalah, trauma, jabatan, atau identitas apapun. Dalam beberapa hal, tanggung jawab ini bahkan tak bisa dipahami dalam kerangka kehadiran. Ia lebih berupa representasi retaknya ego di hadapan YangLain yang diwujudkan melalui "tindakan etis"terhadapnya. Tindakan tersebut bisa mewujud dalam bentuk ke(tak)sadaran seorang tokoh (ego) tentang keterbatasannya saat berhadapan dengan tokoh/objek lain (the other) dalam karya sastra.

\section{Sastra "Yang Epifanik"}

Etika Levinasian merujuk pada penanda epifani Wajah Yang-Lain (le visage d'autrui). Saat berhadapan dengan Yang-Lain, pertamatama yang terlihat olehku adalah Wajahnya. Akan tetapi, Wajah ini bukanlah repsentasifisik sehari-hari, seperti tampan, cantik, jelek, dan sebagainya. Wajah, bagi Levinas (1982: 86), merupakan "signifikasi tanpa konteks". Wajah bermakna bagi dirinya sendiri. Dalam hal ini, Wajah Levinasian sangat mirip dengan 
konsep différance Derridaian. Différance, menurut Derrida, sama sekali bukanlah kata- kata atau konsep, karena kata-kata atau konsep selalu merujuk pada referens yang tetap, sementara différance tidak memiliki eksistensi dan esensi, dan tidak dapat dikategorikan ke dalam satu bentuk kehadiran atau absensi (Al- Fayyadl, 2005: 111). Begitu pula dengan Wajah. Ia tidak bisa digambarkan secara ontologis. Ia melampaui gambaran fenomenologi karena ketidakmungkinanya untuk direngkuh dan dipahami. Dalam konteks karya sastra, Wajah bisa diidentifikasi pada apapun (tokoh, fenomena, objek, situasi, identitas, ruang, waktu, dan sebagainya), apapun yang berusaha dipahami oleh subjek/ego tertentu. Namun demikian, tokoh/objek yang diidentifikasi sebagai Wajah tidak berarti merujuk pada kehadiran atau identitas tokoh/objek tersebut secara temporal maupun spasial. Lebih dari itu, Wajah yang melekat dalam tokoh/ objek itu merujuk pada sesuatu-meminjam istilah Levinas (1974)_- "yang-lain dari Ada" (otherwise than being), sesuatu yang menunda dan mengusik pemahaman kita terhadapnya, sesuatu yang misterius dan sama-sekali asing. Dalam penelitian ini, tokoh-tokoh/objek-objek tertentu yang memendarkan ketakmungkinanya untuk dipahami secara ontologis, baik oleh pembaca maupun tokoh- tokoh lain di dalamnya, diidentifikasi sebagai Yang-Lain (the Other) yang menampakkan diri melalui Wajahnya.

\section{Membaca Putu Wijaya dan Danarto dalam Etika Levinasian}

Tidak semua karya mereka dianalisis dalam penelitian ini. Untuk Danarto (1987), ada dua cerpennya yang dipilih ". $\mathcal{F}^{+}$itu '......" (10-31) dan "Abracadabra" (134-148), sementara karya Putu Wijaya yang dipilih adalah novel Stasiun (1977). Karena keterbatasan ruang, tulisan ini tidak akan secara detail memperlihatkan bagaimana etika Levinasian diterapkan dalam menganalisis ketiga karya tersebut. Namun, setelah membaca dua cerpen Danarto dan satu novel Putu Wijaya itu, ada beberapa catatan penting yang perlu ditegaskan di sini.
Pertama, karya-karya Danarto dan Putu memperlihatkan —apa yang disebut Levinasrespons etis. Yang-Lain, menurut Levinas, menggungatku, meminta pertanggungjawaban padaku, dan menuntutku untuk meresponsnya. Respons ini oleh Levinas diandaikan seperti respons etis Abraham kepada Tuhan. Dalam Genesis 22, Tuhan berkata "Di mana kamu?" Abraham menjawab "Hineni" atau "Di sinilah aku". Kata-kata bineni ini tentu saja melampaui apa yang terungkap dalam kata- ] kata itu sendiri. Dengan mengucapkan bineni, Abraham tidak semata-mata menunjuk pada penempatannya dalam ruang dan waktu. Hineni lebih berupa respons etis yang memang menjadi kewajiban Abraham, suatu kewajiban primordial yang melampaui identitasnya sebagai nabi dan utusan Tuhan. Etika Levinasian memungkinkan respons ini muncul dalam teksteks sastra.

Dalam karya-karya Danarto dan Putu, kita bisa melihat bagaimana tokoh-tokoh di dalamnya telah bertolak dari ego untuk memberikan respons etis pada Yang-Lain. Cerpennya Danarto, misalnya, menyajikan seorang tokoh misterius bernama Rintrik. Rintrik menerima disebut sebagai Rintrik Yang Buta (Danarto, 1987: 20), tapi pada saat yang bersamaan, ia juga menyebut dirinya sebagai Rintrik Yang Tidak Buta (Danarto, 1987: 21). Ia juga pernah menyatakan bahwa Tuhan Maha Suci (Danarto, 1987: 17), tapi pada saat yang bersamaan pula, ia pernah mengakui bahwa Tuhan itu Tidak Suci (1987: 28). Rintrik adalah cerminan seorang tokoh dalam salah satu karya sastra yang benar-benar paradoksal. Sementara itu, dalam Stasiun karya Putu, bisa dilihat bagaimana tokoh yang bernama "orang tua" harus berkali-kali merespons kehadiran orang lain (seperti dirinya), yang tampak dengan cara dan wujud yang berbeda-beda. Respons etis ini, seperti yang diungkapkan Levinas, tidak bisa kita pahami secara ontologis.

Apa yang ditampilkan oleh Putu dan Danarto dalam dua karya sastra ini membuat subjek-meminjam istilah Robert Eaglestone (1997: 175)_ “tidak betah dengan teks". 
Kesadaran dan horizon harapan subjek seketika runtuh saat berhadapan dengan tokoh-tokoh yang ditampilkan oleh Danarto dan Putu. Implikasinya, seperti yang sudah dijelaskan di depan, ketegangan ini memungkinkan lahirnya relasi etis antara subjek/pembaca dan tokohtokoh/objek dalam karya sastra. Relasi ini muncul saat subjek tidak lagi mampu memahami tokoh-tokoh tersebut dalam kesadaran dan totalitas yang utuh. Totalitas ego/subjek kita saat itu juga "tersandera" saat berhadapan dengan tokoh- tokoh 'disruptif', yang mengusik pemahaman kognitif sehari-hari.

Kedua, beberapa adegan dan momen tertentu dalam karya-karya Putu dan Danarto memungkinkan terinduksinya beberapa "benang-merah" etika Levinasian. "Benang merah" itu antara lain: transendensi, bahasa, keadilan, dan agama tanpa-agama. Transendensi merupakan momen keterpecahan saat diri (the self) tengah merasakan bahwa keberadaannya tak lagi berkuasa karena ada Yang-Lain yang selalu mengusik dan menganggu totalitasnya. Momen transendensi ini dirasakan, misalnya, oleh Rintrik dalam kesadarannya untuk lebih menganggap maut (kematian) sebagai sesuatu yang eksterior, yang berada di luar pikiran (pengetahuan dan ontologi). Menurut Rintrik, sebagaimana yang juga pernah dinyatakan oleh Levinas, momen kematian adalah saatsaat di mana ego telah mencapai puncaknya. Di saat (menjelang) kematian inilah (le moir), segala bentuk totalitas ego seketika retak karena di-sana-yang-akan-segera-datang, ada Wajah Yang-Lain yang menunggunya, yang akan meruntuhkan totalitasnya. Kematian tak bisa diontologisasi oleh pemikiran atau logika apapun. Yang bisa dilakukan adalah pasrah, semacam "kepasifan radikal" (radical passivity)_kata Blanchot (Caputo, 1997: 78). Namun, kepasifan ini selalu menyimpan gairah untuk menjemput Yang-Lain, seperti gairah yang dirasakan Rintrik di saat menjelang kematiannya. "Untuk terakhir kalinya, apa keinginanmu?" "Syahwat yang besar sekali", kata Rintrik, "melihat Wajah Tuhan!" (Danarto, 1987: 30).
Sementara itu, dalam cerpen "Abracadabra", terdapat benang merah yang lain yakni keadilan. Momen keadilan ini dirasakan oleh Hamlet, lagi-lagi ketika sedang sekarat, saat ia meminta untuk menghapuskan kasta-kasta dalam bahasa. Baginya, sebutan pangeran, raja, priyai, dan sejenisnya sarat dengan kekuatan untuk merengkuh dan menguasai Yang-Lain (Danarto, 1987: 135-136). Hamlet melihat bahwa bahasa-bahasa semacam ini memungkinkan terjadinya ontologisasi bahasa subjek-objek. Bahasa yang sarat dengan kastakasta, bagi Levinas, yang juga diamini oleh Hamlet, diam-diam menjustifikasi struktur hierarkis yang tidak saja berimplikasi pada kekerasan fisik, namun juga kekerasan yang paling elementer dan eksistensial: "kekerasan metafisik" (violence of metaphysics), yakni kekerasan yang terjadi ketika ego berusaha menjadikan manusia lain sebagai objek yang bisa direngkuh dan ditematisasi melalui kategori-kategori reprentasional tertentu.

Momen agama tanpa-agama, yakni beragama tanpa dibatasi oleh institusi formal bernama "agama", dapat kita telusuri pula dalam cerpen " $\mathrm{O}^{+}$" ". Tuhan, bagi Rintrik, adalah Yang-Maha-Lain, yang tak sepenuhnya bisa dipahami. Tentu saja, Rintrik bukanlah seorang nihilis, apalagi atheis, karena ia pun mengakui Tuhan. Tapi pernyataannya bahwa "Akulah Tuhan" (hlm. 26) menunjukkan proksimitasnya dengan Yang-Maha-Lain itu. Rintrik mungkin saja merasakan proksimitas itu saat ia menyebut dirinya Tuhan (begitu dekatnya Tuhan dengan Rintrik membuat ia "pasif", tak bisa berkata apa-apa, tak bisa menggambarkan kedekatannya dengan Tuhan, tak bisa mengekspresikan Tuhan itu sendiri, sehingga ia pun lebih memilih untuk berkata Akulah Tuhan). Tetapi, ketika Rintrik mengatakan dirinya Tuhan, ia bukan berarti Tuhan itu sendiri. Ia hanya ingin menegaskan bahwa segala tematisasi, konsepsi, dan ontologisasi yang berusaha mendeskripsikanTuhan tak akan pernah bisa berhasil. Dengan laku yang tak bisa dipahami, dengan sikapnya yang penuh misterius, Rintrik seolah menegaskan ke(tak)hadiran Tuhan 
Yang Maha Lain. Ketika engkau, manusia, tak bisa sepenuhnya memahami diriku, bukankah itu juga berlaku saat engkau ingin memahami Tuhanmu? Begitulah kira-kira yang hendak dinyatakan Rintrik. Ia memang beragama, bertuhan pada-Nya. Tetapi, kebertuhanannya dilakukan dengan cara mengimani-Nya, "pasrah" pada-Nya (Danarto, 1987: 27). Iman dan kepasrahan inilah yang bagi Rintrik, juga bagi Levinas dan Derrida, yang membedakan diri dengan agama dan dogma. Iman tak punya laku, tak punya identitas. Kepasrahan juga menunjukkan kepasifan primordial atas ketundukan seorang budak yang-meminjam istilah Levinas "tersandera" (bostage) oleh kehadiran Yang-Lain, Yang-Tak-Terbatas.

Keempat, karya-karya Danarto dan Putu menandai benang merah yang terakhir, sekaligus yang terpenting, dalam etika Levinasian, yakni bahasa. Bagi Levinas, ada dua jenis bahasa, yakni le Dit atau the Said ('yang terucap') dan le Dir atau the Saying ('yang mengucap'). The said adalah struktur, bunyi, atau bentuk bahasa yang keluar dari ujaran, sementara the saying adalah sesuatu yang ada di balik the said, yang tak bisa dirumuskan kehadirannya, dan menolak untuk ditematisasi. Perbedaannya, the said biasanya diucapkan untuk merumuskan dan mengobjektivikasi Yang-Lain, sementara the saying tidak demikian. The saying mau membiarkan Yang-Lain tetap dalam kelainannya. The saying adalah penanda transendensi kata-kata yang melampaui pemahaman kita atas objek tertentu. Dalam karya-karya Danarto dan Putu, kita bisa melihat bagaimana the saying ini beroperasi. Pernyataan Rintrik, Hamlet, dan "orang tua" sering kali tak bisa kita pahami secara ontologis. Salah satu contohnya bisa kita telusuri dalam cerpen "Abracadabra". Dalam cerpen ini, kita bisa melihat bagaimana Hamlet begitu sulit menceritakan kisah perjumpaannya dengan Roh dan kematian. Bukan saja karena Roh dan kematian adalah Yang-Lain bagi Hamlet, namun karena Hamlet berusaha mendeskripsikan Roh dan kematian, dunia Yang-Lain, dalam struktur kata-kata yang baku. "Kesukaran saya yang pertama", kata Hamlet, "Adalah bahwa saya harus menerjemahkan dunia pengalaman saya ke dalam bahasa saudara. Itu rumit dan terasa mokal" (Danarto, 1987: 141-145) Ucapanucapan Hamlet tentang Roh dan kematian memperlihatkan bahwa apa yang-terucap (the said) seringkali tak bisa menstrukturasi yangmengucap (the saying). Roh, dunia Yang-Lain itu, seolah-olah menolak untuk ditematisasi dengan the said. Meskipun Hamlet telah menceritakan pengalamannya itu kepada pembaca melalui the said, namun ceritanya seringkali tak pernah selesai, meloncat-loncat, seakan-akan ada sesuatu yang tak bisa dikuasai oleh bahasa ontologis the said. Itulah the saying, semacam "bahasa-diam" yang untematizable, labirin yang melampaui struktur bunyi dan kesadaran the said.

\section{Penutup}

Alih-alih memberi ringkasan atau kata penutup atas pembahasan di atas, bagian ini dikhususkan untuk menjelaskan beberapa kemungkinan - atau katakanlah, implikasiimplikasi lanjutan - yang mungkin luput dibicarakan dalam diskusi mengenai relasi antara etika Levinasian dan sastra. Tentu saja, masih ada banyak konsep Levinas yang belum diungkapkan dalam tulisan ini, dan hal tersebut menyiratkan beberapa tema yang dapat digarap di kemudian hari.

Pertama, soal narasi. Bagaimana Levinas menjelaskan narrating subject dan narrated object dalam karya sastra? Isu ini menjadi menarik jika etika Levinasian didialogkan dengan konsep narrator- characternya Genette atau reflectornarration-nya Jamesian (Genette, 1980: 248). Jika Levinas percaya bahwa subjek tidak lagi berada dalam oposisi yang nyaman dengan objek, berarti posisi narrator juga mengalami ketegangan dilematis: di satu sisi narator berperan sebagai experiencer, sementara di sisi lain ia tidak serta merta menjadi narator yang serba tabu, karena objek yang dinarasikan tidak benar-benar bisa direpresentasikan secara total. Pertanyaannya adalah bagaimana bentuk relasi etis yang terbangun antara narator sebagai narator dan narator sebagai karakter? 
Dan bagaimana pula keduanya dihubungkan dengan objek yang dinarasikan? Di sini, konsep excendance (hasrat spontan untuk keluar karena menyadari akan keterbatasan diri) yang digagas Levinas (1982: 262) bisa menjadi gagasan penting.

Kedua, mengenai representasi. Jika Levinas percaya bahwa the other tidak bisa direngkuh dalam totalitas kedirian subjek, apakah Levinas dengan demikian adalah antirepresentasionalisme? Gagasan Levinas di sini akan menarik jika didiskusikan dalam kaitannya dengan konsepsi Sublimenya Lyotard (1984: 81) atau Realnya Žižek (1989: 31). Jika Žižek percaya bahwa Yang-Riil adalah dunia antahberantah yang tak terepresentasikan secara linguistik dalam pemahaman subjek dialektis (sebagaimana Lacan), Lyotard meyakini bahwa representasionalisme merupakan bagian dari sistem megapolis yang terus menerus menciptakan konsensus (sesuatu yang secara tajam dikritik oleh Lyotard). Diskusi tentang keduanya dan relasinya dengan Levinas akan membuka ruang baru bagi apa yang dikenal dengan "representasi" dalam karya sastra, dan bagaimana representasi itu harus diposisikan dan dikritik melalui strategi etika negativitas.

Ketiga, tentang sensibilitas. Sensibilitas, dalam konsepsi Levinas, dapat dipahami sebagai sesuatu yang berbeda dengan kognisi subjek. Jika selama ini sensibilitas (modern) hanya dipahami sejauh subjek memahami objek dengan keinginan untuk menguasai dan mendominasinya, maka etika Levinasian memahami sensibilitas sebagai keterbukaan dan penyapaan (interpelasi) (Levinas, 1974: 15). Dalam penyapaan, tidak ada tendensi untuk merengkuh; yang ada hanyalah ketersediaan subjek untuk membuka diri pada liyan. Sensibilitas Levinasian ini akan menarik didiskusikan dalam kaitannya dengan gagasan Bataille (1985: 117, 124) tentang expenditure, sesuatu yang melampaui akumulasi dan produksi. Dalam ranah etis, expenditure selalu menghantui dan mengusik prinsipprinsip pertimbangan "ekonomis" tentang keseimbangan, pemikiran kalkultaif, yang didasarkan pada prinsip kesamaan dan totalitas. Keempat, tentang resepsi. Dalam The Implied Reader (1974: 274), Iser meganggap bahwa 'teks hanya mungkin hidup ketika ia direalisasikan', dalam konkretisasi pembaca. Secara psikologis, dikotomi subjek/pembaca dan objek/teks benar-benar dileburkan dalam teori resepsi. Akan tetapi, jika dipahami lebih mendalam, konsepsi Iser tentang 'konkretisasi' ini memiliki kesamaan dengan teori intensionalitasnya Husserl. Pembacaan, dalam teori resepsi, berusaha mengkoretisasi potensi yang tak terbatas dari teks. Ia berusaha menyintesiskan intensionalitas pembaca dan ketakterbatasaan teks, sehingga teks bisa dikonkretisasi sesuai dengan kehendak pembaca. Jika demikian ihwalnya, dialog antara Iser di satu sisi dan Levinas serta Blanchot di sisi lain bisa jadi menarik. Blanchot menawarkan puitika ruang (poetics of space) yang mempertanyakan kehendak subjek untuk mendominasi teks, sementara Levinas menawarkan etika alteritas untuk memenjarakan subjek dalam proses pembacaan yang tak pernah habis dalam berbagai pluralitas bahasa dan suara (dalam bahasa Bakhtin). Jika sentralitas subjektif pembaca dihadapkan pada ketegangan semacam ini, mungkinkah konkretisasi itu dilakukan?

Yang terakhir, dan mungkin yang terpenting, adalah isu pascakolonial. Dalam beberapa hal, konsep Homi Bhaba (1994: 37) tentang ambang-batas, in-between, ruang- antara, liminalitas, dan sebagainya bisa dipahami dalam relasinya dengan konsep Levinas tentang hostage. Jelas, ada keterkaitan yang sangat rigid dalam kedua pemikiran tersebut. Diskusi ini akan semakin menarik dilihat kemungkinan implikasinya ketika disadari bahwa etika Levinasian lahir di tanah Eropa, yang jelasjelas berbeda dengan sejarah sosial, politik, dan kebudayaan Indonesia sebagai negara pascakolonial. Memanfaatkan analisis ini untuk menelusuri jejak-jejak traumatik dalam karyakarya sastra Indonesia bisa jadi tema diskusi yang unik karena bagaimanapun gagasan etika dan politik Levinas tidak bisa dilepaskan dari pengalaman traumatiknya terhadap Holocoust. 
Masih ada banyak pertanyaan lain yang dapat dieksplorasi lebih jauh. Namun, yang jelas adalah bahwa pembacaan etis dan/atau "etikopolitis" sudah saatnya mendapat tempat tersendiri dalam hamparan teori kesusastraan kontemporer. Alih-alih sebagai proyek final, apa yang ditawarkan dalam tulisan ringkas ini hanyalah upaya awal dalam memproblematisasi pemahaman kita selama ini tentang "etika" dan sastra. Benarkah etika yang selama ini dipahami memberi kita kenyamanan layaknya kenyamanan di sebuah rumah? Atau malah apa yang kita sebut sebagai "etika" dan "rumah" itu ternyata tak memberi apa-apa selain kegalisahan eksistensial terus-menerus? Dan bagaimana jadinya jika kegelisahan itu tak pernah berakhir: bahwa kita selalu merasa terasing justru dalam rumah yang kita diami selama ini?

\section{Daftar Pustaka}

Al-Fayyadl, Muhammad. 2005. Derrida. Yogyakarta: LKiS.

Bachelard, Gaston. 1964. The Poetics of Space, terj. Maria Jolas. New York: Orion Press.

Bataille, Georges. 1985. Visions of Excess: Selected Writings 1927-1939, ed. dan terj. Allan Stoekl. Manchester: Mancester University Press.

Bhaba, Homi K. 1994. The Location of Culture. New York: Routledge.

Caputo, John D. 1997. The Prayer and Tears of Jacques Derrida. Bloomington dan Indianapolis: Indiana University Press.

Danarto. 1987. . “' Godlob. Jakarta: Pustaka Grafiti Press.

1987. Abracadabra, Godlob. Jakarta: Pustaka Grafiti Press.

Davis, Todd F. \& Kenneth Womack. 2001. "Preface: Reading Literature and the Ethics of Criticism", dalam Todd F. Davis dan Kenneth Womack (eds.). Mapping the Ethical Turn: A Reader in Ethics, Culture, and Literature Theory. Charlottesville: University Press of Virginia.
Derrida, Jacques. 1978. "Violence and Metaphysics: An Essays on Thought of Emmanuel Levinas", dalam Writing and Difference, terj. dan anotasi Alan Bass. Chicago: The University of Chicago Press.

Eaglestone, Robert. 1997. Ethical Criticism: Reader after Levinas. Edinburgh: Edinburgh University Press.

Eskin, Michael. 2004. "Introduction: The Double 'Turn' to Ethics and Literature?" Poetics Today, vol. 25, no. 4, Musim Dingin.

Genette, Gérard.1980. Narrative Discourse, terj. Jane E. Lewin. Oxford: Blackwell.

Harpham, Geoffrey Galt. 2003. "Ethics", dalam Frank Lentrichia dan Thomas McLaughlin (eds.). Critical Terms for Literary Study. Chicago: University of Chicago Press, cet. II.

Herman Jacobowitz, -Wiesel, Levinas, and Chouchani", dalam JewishMagazine. Online: http://www.jewishmag.com/118mag/ wiesel-levinas-chouchani/wiesel-levinaschouchani.htm [Diakses pada 23 Mei 2012].

Iser, Wolfgang. 174. The Implied Reader. Baltimore: Johns Hopkins University Press.

Levinas, Emmanuel. 1989. "Ethics as First Philosophy", dalam Seán Hand (ed.). The Levinas Reader. Cambridge: Blackwell, Ltd. 1989. "God and Philosophy", dalam Seán Hand (ed.). The Levinas Reader. Cambridge: Blackwell, Ltd. 1989. "The Other in Proust", dalam Seán Hand (ed.). The Levinas Reader. Cambridge: Blackwell, Ltd. . 2001. "The Philosopher and Death", dalam Jill Robbins (ed.). Is It Righteous To Be?: Interviews with Emmanuel Levinas. Stanford: Stanford University Press. 1982. Ethics and Infinity: Conversations with Philippe Nemo, terj. Richard A. Cohen. Pittsburgh: Duquesne University Press. 
. 1974. Otherwise than Being, or Beyond Essence, terj. Alphonso Lingis. Pittsburg: Duquesne University Press.

- 1969. Totality and Infinity: An Essay on Exteriority, terj. Alphonso Lingis. Pittsburg: Duquesne University Press.

Lyotard, Jean-François. 1984. The Postmodern Condition, terj. Geoff Bennington dan Brian Massumi. Manchester: Manchester University Press.

Newton, Adam Zachry. 1995. Narrative Ethics. Cambridge: Harvard University Press.

Peperzak, Adriaan Theodor., 1997. Beyond: The Philosophy of Emmanuel Levinas. Evanstone: Northwestern University Press.

Robbins, Jill. 1999. Altered Reading: Levinas and Literature. Chicago: University of Chicago Press.

Schwarz, Daniel R. 2001. "A Humanistic Ethics of Reading", dalam Todd F. Davis dan Kenneth Womack (eds.). Mapping the Ethical Turn: A Reader in Ethics, Culture, and Literature Theory. Charlottesville: University Press of Virginia.

Wijaya, Putu. 1977. Stasiun. Jakarta: Pustaka Jaya. 